\title{
HEGYI ÁDÁM
}

egyetemi docens

ORCID: orcid.org/0000-0002-9575-5531

SZTE BTK Kulturális Örökség és Humán Információtudományi Tanszéke

hegyi@bibl.u-szeged.hu

\section{AKADEMISCHE FESTKULTUREN VOM MITTELALTER BIS ZUR GEGENWART. ZWISCHEN INAUGURATIONSFEIER UND FACHSCHAFSTPARTY}

\author{
Herausgegeben von Martin Kintzinger, Wolfgang Eric Wagner, Marian Füssel \\ unter Mitarbeit von Stefan Hynek \\ Veröffentlichungen der Gesellschaft für Universitäts- und Wissenschaftsgeschichte, \\ 15., Schwabe, Basel, 2019, VIII, 403 lap
}

1995-ben a Bern melletti Münchenwilerben német, osztrák és svájci történészek elhatározták, hogy az addig egyénileg végzett kutatómunkájukat szervezett körülmények között kívánják folytatni, ezért megalapították az egyetem- és tudománytörténettel foglalkozó társaságukat (Gesellschaft für Universitäts- und Wissenschaftsgeschichte, rövidítve GUW). Kezdeményezésüket siker koronázta, és mára egy olyan jelentős szervezetet tudhatnak a hátuk mögött, amely rendszeresen szervez nemzetközi konferenciákat, a Schwabe kiadó adja közre sorozatukat, szakfolyóiratot jelentetnek meg, és saját kutatási projektet vezetnek.

A GUW kétféle konferenciát szokott szervezni. Az első típusba a workshopok tartoznak, amelyeken fiatal kutatók, doktoranduszok ismertetik kutatási eredményeiket. A másik típusba azok a nemzetközi konferenciák tartoznak, amelyek előadásai szerkesztett változatban jelennek meg a társaság könyvsorozatában. A sorozat a Veröffentlicbungen der Gesellschaft für Universitäts- und Wissenschaftsgeschichte címet kapta. A sorozatban átlagosan két évente jelenik meg egy új kötet, míg a Jabrbuch für Universitätsgeschichte évente egy számmal jelentkezik. A társaságnak 2012-ben sikerült saját kutatási projektet is létrehoznia. Ezt Rainer Christoph Schwinges vezeti, és a Német-római Birodalom egyetemein 1250 és 1550 között tanult összes hallgató prozopográfiáját állítják a segítségével össze. Schwinges egyébként a társaság sorozatának is a főszerkesztője.

Recenziónkban bemutatásra kerülő kötet 2019-ben a GUW könyvsorozatában jelent meg. Ez a könyv már a sorozat 15. része, és 2021 szeptemberében fog megjelenni a 16. kötet, amely az egyetemek és a politika kapcsolatával a középkortól a közelmúltig foglalkozik majd. ${ }^{1}$

A bécsi egyetem 2015-ben ünnepelte alapításának 650. évfordulóját. A jubileum ráirányította a szakma figyelmét arra, hogy az egyetemek kultúrtörténetében az ünnepségek fontos szerepet játszottak. Éppen ezért határozott a GUW úgy, hogy Bécsben szervezi meg konferenciáját, amely az egyetemek és a diákok ünneplési szokásaival foglalkozott. Természetesen a konferencia kitért a bécsi egyetem jubileumára, de nem ez volt a főtémája. A cél az volt, hogy a középkortól a közelmúltig egy áttekintő képet alkossanak az egyetemi ünnepségek történetérôl.

A konferencia előadásainak írott változatát Martin Kintzinger, Wolfgang Eric Wagner és Marian Füssel szerkesztette össze. A szerkesztőbizottság tagjai közül ketten - Kintzinger és Wagner azonos egyetemen dolgoznak. Kintzinger a középkor történetének, Wagner a történeti segédtudományoknak a professzora Münsterben. Füssel viszont Göttingenben a kora újkor és a tudománytörténet professzoraként dolgozik. A kötetben összesen tizenhat tanulmány szerepel a német szerkesztőkön kívül osztrák, finn és ír szerzők tollából.

\footnotetext{
${ }^{1}$ Martin KINTZINGER und Wolfgang Eric WAGNER und Ingo RUNDE, Hrsg., Hoschule und Politik. Politisierung der Universitäten vom Mittelalter bis zur Gegenwart, Veröffentlichungen der Gesellschaft für Universitäts- und Wissenschaftsgeschichte 16 (Basel: Schwabe, 2021).
} 
A bevezetô tanulmány egy historiográfiai áttekintés az egyetemi ünnepekről. Marian Füssel szerint alapvetően három tényező határozza meg az egyetemi ünnepségeket: a gyakorlati megvalósítás, a helyszín és a média. Írásában arra hívja fel a figyelmet, hogy az egyetemi ünnepi szokások az istentiszteletből alakultak ki.

Az ünnepségek létrejöttét Wolfgang Eric Wagner is a megvalósítás, a helyszín és a média hármasa alapján vizsgálja. Wagner úgy véli, hogy a késő középkorban „találták fel” az egyetemalapítási jubileumokat, de azok gyakorlati megvalósítása, helyszíne és médiája lényegesen eltér a mai szokásoktól. Erre példaként a bécsi egyetem alapításának 650. és a lipcsei egyetem alapításának 600. évfordulójára rendezett ünnepségeket hozza fel. A középkor végén viszont nem sajtónyilvános eseményeken, hanem miséken emlékeztek meg az alapításról. Kölnben, Löwenben és Lipcsében mindegyik egyetemi anyakönyvben találunk olyan adatokat, amelyekből kiderül, hogy az alapítás napját évente egy hálaadó mise keretében ünnepelték meg. A 15. század végére aztán egyre több egyetemen terjedt el az a szokás, hogy az alapítás kerek évfordulóit kell megünnepelni. Így például Erfurtban, Krakkóban és Rostockban a 100. évfordulót ünnepelték meg.

Ezek után jogosan merül fel a kérdés: egyáltalán miért ünneplik az egyetemek az alapítási évfordulóikat? Markus Drüding szerint a 19-20. században a nyugati civilizációban a jubileumok ünneplése robbanásszerű növekedésnek indult, amely nemcsak az egyetemeken, hanem más területeken is megmutatkoztak. Drüding úgy gondolja, hogy ennek gazdasági, politikai és társadalmi okai vannak. A német egyetemek anyagi alapjainak biztosítása szempontjából létfontosságú kérdés volt minél több hallgatót bevonzani az intézményekbe. Az ünnepségek ezt a gazdasági indíttatású célt szolgálták ki, hiszen népszerűsítették az egyetemi kultúrát. Mindeközben a politikai is felhasználta saját céljaira az egyetemeket, amelyet a nemzetszocialista és kommunista időszakból vett példákkal igazol. Végül Drüding a társadalmi okok közé sorolja az egyetemeknek a társadalom múködésére, és a társadalom gondolkodására gyakorolt hatását.

Jubileumok az egyetemek falain kívül is zajlottak, de néhány esetben azok szoros kapcsolatba kerültek az egyetemekkel. A reformáció 300. évfordulója alkalmából Wartburg várában több száz német diák gyűlt össze. Joachim Bauer a jénai hallgatók példáján keresztül mutatja be, hogy ez az ünnepség valójában nem a hitújitást, és nem a napóleoni háborúk végét köszöntötte, hanem létrehozta a modern német politikai gondolkodást, és ezáltal a német egység megvalósításának lehetőségét.

Arra is találunk példát, hogy olyan helyeken ünnepelték az egyetemeket, amelyek nem voltak az egyetemek részei. Amikor IV. Rudolf 1365-ben egyetemet alapított Bécsben, akkor az uralkodó nagy terveket szőtt. Korai halála ennek megvalósítását nem tette lehetővé, de arra még maradt ideje, hogy pár nappal az alapítólevél kibocsátása után mindenszentek tiszteletére egy káptalant is alapítson. Renate Kohn tanulmányában azt mutatja be, hogy a bécsi Szent István templomban néhány éve talált középkori freskók valójában graffitik, amelyek az egyetem alapításának megünneplésével vannak összefüggésben.

Ulrike Denk szintén a bécsi egyetemmel kapcsolatban talált érdekes forrásokat. Tanulmányában azt a folyamatot mutatja be, hogyan alakultak át a középkori eredetű diákbeavatási szertartások az egyetem hivatalos ceremóniájává. Denk arra hívja fel a figyelmet, hogy az ilyen beavatási rítusokról viszonylag kevés forrás maradt fenn, noha az egyetem matrikulájában is vannak rá vonatkozó adatok, mégis valójában azokat a dokumentumokat lehet az események rekonstrukciójához felhasználni, amelyek részletesen leírják a beavatás alkotóelemeit. Ilyen Gandolph Wanger 1551 ben összeállított krónikája, amely egy beavatási szertartást ismertet.

Az egyetemek történetében az is előfordult, hogy a diákok túlzásba vitték az ünneplést. Matthias Hensel a jénai egyetemet hozza fel erre példaként, ugyanis Jénában a kora újkorban a diákkarneválok, farsangi mulatságok olyan szélsőséges dorbézolásba fordultak át, hogy azokat mai szemmel egyszerűen deviánsnak mondanánk. Éppen ezért 1647-ben az egyetem vezetése betiltotta ezek a „szakesteket."

A diákélet szerves része ma is a diplomaosztó ünnepség. Heike Bungert az amerikai felsőoktatás példáján keresztül mutatja be, hogyan ünnepelték meg a 19. és a 20. században a hallgatók 
diplomájuk megszerzését. Bungert tanulmányában kitér arra, hogyan alakult a női egyenjogúság helyzete az amerikai egyetemeken, és részletesen ismerteti, miért jellemző az amerikai felsőoktatásban, hogy ismert politikusok, közemberek vagy színészek mondanak ünnepi beszédeket diplomaosztó ünnepségeken.

Richard Kirwan a kora újkori német egyetemek alapítóünnepségeinek alkalmából megjelent reprezentációs célú köteteket elemzi. Többek között kitér az 1576-ban az altdofi egyetem tiszteletére 312 oldal terjedelemben megjelent munkára is. Szintén elemzi azt a kötetet is, amelyet 1623-ban az altdorfi egyetem teljes, négyfakultású egyetemmé válásának alkalmából nyomtattak ki. Kirwan szerint az egyetemi ünnepi kötetek népszerűsége összefügg azzal, hogy 1560 és 1630 között a német egyetemeken a tudományos célú könyvek kiadásában egy ugrásszerú növekedés történt. Az egyetemi jelvények és szimbólumok története összefügg politikai változásokkal. A bécsi egyetemen az első világháború után vezették be a professzori talárt, amely összefüggésben áll azzal, hogy a szétesett birodalom olyan új jelképeket kívánt használni, amely nemzetek feletti volt, és elfogadható mindenki számára. Marija Wakounig arra hívja fel a figyelmet, hogy Bécsben a professzori talár bevezetés a 20. században kétszer is megtörtént: először 1927-ben, majd 1965-ben az egyetem alapításának 600. évfordulóján. Susana Zapke szintén a bécsi egyetem kapcsán mondja azt, hogy az államhatalom befolyásolta az egyetemek múködését is. Zapke viszont ezt IV. Rudolf 1365-ös egyetemalapítása kapcsán mutatja be. Szerinte a városi utcai zenélés, a körmenetek és vallási rítusok jelentősen megváltoztak Bécsben az egyetemalapítás és az uralkodói akarat hatására. A zene az egyetemi ünnepségek életében mindig is fontos szerepet játszott. Pieter Dhondt szerint a 19. századi svéd egyetemek esetében a dalok, a közös énekek a romantika nacionalizmusát mutatják be, ugyanis a dalszövegekből, előadásmódokból olyan rejtett kommunikációs csatornákat is lehet rekonstruálni, amelyek a modern nemzettudat és nemzetállamok kialakulását segítették elő. Harald Lönnecker ezt a gondolatmenetet folytatja tanulmányában, amelyben a német egyetemek zenekultúráját mutatja be az első világháborúban és a nemzetiszocialista időszakban. Lönnecker úgy véli, hogy a zenetörténet sok új adattal szolgál az egyetemi ünnepségek történetéhez is, elemzésében ennek a komlpex kutatásnak a vázlatát rajzolja meg.

Mint említettük a kötet a bécsi egyetem alapításának 650. évfordulója alkalmából jelent meg, ezért nem meglepő, hogy a könyvben további két olyan tanulmány is szerepel, amelyek csak Béccsel foglalkoznak. Meta Niederkorn-Bruck történeti antropológiai szempontú megközelítést alkalmaz elemzésében, ugyanis az emberi szenvedésre és a halálra való emlékezést mutatja be. Bruck azt rekonstruálja, hogy a bécsi egyetem alapítása után eltelt két évszázadban milyen szerepet játszott az egyetem múködésében a halottkultusz, és ehhez kapcsolódóan milyen ünnepi alkalmakon emlékeztek meg az alapító és más patrónusok haláláról. Karl Ulb IV. Rudolf alapítóoklevelét elemzi, amelyet ugyan már régóta ismer a történettudomány, de Ulb új szempontú megközelítést alkalmaz: milyen utópisztikus elvárásokat támasztottak a 14. században egy egyetemmel szemben? A kötet témáját nagyon jól összefoglalja Winfried Müller eszmefuttatása. Müller középkori, koraújkori, újkori és jelenkori példákat felsorolva mutatja be, miért szeretik az emberek és az egyetemek is az ünnepségeket. Miért népszerűek a kerek évfordulók megünneplései, és hogyan változtak az egyes korszakok egyetemi ünneplési szokásai.

Összefoglalva azt mondhatjuk, hogy a GUW egy igen értékes tanulmánykötetet tett közzé, egyedüli hiányosságának a mutatók felületességét tekinthetjük, ugyanis a mutatók csak a főszöveget mutatózzák, a lábjegyzeteket nem. Ráadásul a szakirodalom is csak a lábjegyzeteket bogarászva kereshető vissza, a szerkesztők nem készítettek különönálló bibliográfiát. 